\title{
Measuring Trade Integration in Africa
}

\author{
Antoine Bouët \\ IFPRI, Washington D.C., US \& GREThA, Bordeaux, France \\ Lionel Cosnard \\ AgroParisTech, Paris, France \\ David Laborde \\ IFPRI, Washington D.C., US
}

\begin{abstract}
This paper reviews the literature on the measurement and characterization of trade integration in Africa. We offer the complete evaluation of available indicators and methodologies. The indicators include those that have recently emerged from network analysis like indicators of trade in value-added commodities. It is concluded that Africa is characterized by weak trade integration, particularly with the rest of the world. This is naturally explained by high trading costs that are evaluated by tariffs, non-tariff measures, and other trade costs, such as those related to border and documentary compliance. The region's small number of trading partners and low product diversification are also noticeable. However, the use of more refined indicators shows that intra-African trade is relatively high when compared with trade with other continents, contrary to what can be concluded from some simple trade share indicators.
\end{abstract}

\section{JEL Classification: F14, F15}

Keywords: Trade Integration, Trade Indicators, Africa

\footnotetext{
* Corresponding author: Antoine Bouët; International Food Policy Research Institute, Markets Trade and Institutions Division, 1201 Eye Street NW, Washington DC, 20005-3915, USA, Tel: +1 2028625600, Fax: +1 2028625606, E-mail: a.bouet@ cgiar.org.

Co-Author: Lionel Cosnard; AgroParisTech, 16 rue Claude Bernard, Paris, F-75231, France, Tel: +33 144081843, Fax: +1 44081600, E-mail: lionel.cosnard@u-bordeaux.fr.

David Laborde; International Food Policy Research Institute, Markets Trade and Institutions Division, 1201 Eye Street NW, Washington DC, 20005-3915, USA, Tel: +1 2028625600, Fax: +1 2028625606, E-mail: a.bouet@cgiar.org.
} 


\section{Introduction}

In this paper we measure trade integration in Africa. Our main conclusions are as follows: (1) Africa's low participation in global trade may be the consequence of high administrative costs at the borders, particularly compliance and documentary costs, as well as of elements other than barriers to trade, such as African economies' lack of competitiveness and/or supply-side factors; (2) regional trade in Africa is relatively high in comparison with its economic size and with other regions and not relatively low as often asserted by many international institutions (UNECA and AfDB 2010, Brenton and Isik 2012, Ben Barka 2012) . This growing trade introversion may be explained by Africa's increasing loss of competitiveness relative to the rest of the world; (3) an important feature of African trade is the limited number of products exported by the region.

At the African Union Summit in Malabo (Equatorial Guinea) in June 2014, African governments adopted the Malabo Declaration on Accelerated Agricultural Growth and Transformation for Shared Prosperity and Improved Livelihoods, a set of concrete agricultural goals to be reached by 2025. Among these goals is the resolution to triple, by the year 2025, intra-African trade in agricultural commodities and services. (Malabo Declaration 2014 $4^{1}$ )

There appears to be a consensus in the academic literature regarding Africa's low level of participation in world trade. Sachs and Warner (1997) notice that Africa missed out on the globalization trend in the late twentieth century. Subramanian and Tamirisa (2001) also find support for under-trading by African countries. Bouët et al. (2008b) conclude that insufficient trade infrastructure plays a role in explaining Africa's low trading status.

In 2012, the African Development Bank (Ben Barka 2012) underlined Africa's low participation in world trade, stating that in 2009, Africa's contribution to global trade stood at just under 3 percent of global trade when compared with close to 6 percent for Latin America and a significant 28 percent for Asia (Ben Barka 2012). However, these last percentages do not actually reveal much as there is no benchmark to support such a comparison. According to the $\mathrm{IMF}^{2}$, Africa's share of world GDP was 3.5 percent in 2013, and 3 percent cannot be considered to be abnormally low. Furthermore, Latin America's share of world GDP is 5.7 percent, whereas Asia's share is 25 percent. This

\footnotetext{
IMF Data Mapper, International Monetary Fund.
}

${ }^{2}$ IMF Data Mapper, International Monetary Fund. 
lack of benchmark is an important concern in several official publications.

With regard to regional trade (i.e., trade within the continent of Africa, which is the stated objective of the Malabo Declaration), however, perspectives differ. On the one hand, many international institutions agree on Africa's relatively low level of regional trade. United Nations Economic Commission for Africa and African Development Bank (UNECA and AfDB 2010) conclude that on average, over the past decades, only about 10 to 12 percent of African trade has taken place with other African nations. On the other hand, approximately 40 percent of North American trade occurs among North American countries. Similarly, about 63 percent of Western European trade takes place among Western European nations. In 2012, the World Bank (Brenton and Isik 2012) cited Africa's low level of intra-regional trade as well as the continent's fragmentation. The African Development Bank (Ben Barka 2012) underlined that in 2009, intra-African trade accounted for about 10 percent of the continent's total trade. This is far below the levels of intra-regional trade achieved in Latin America and Asia, 22 percent and 50 percent, respectively.

However, the academic literature comes to a different conclusion. Foroutan and Pritchett (1993) find no evidence that trade flows within Sub-Saharan Africa (SSA) are relatively low because of policy or the lack of infrastructure. Rather, they observe that actual trade in the region corresponds to the flows predicted by gravity equations: the low degree of trade among SSA countries can be explained by those countries' low levels of GDP. Yang and Gupta (2007) conclude that even if intra-regional trade in Africa is lower than that in other regions, trade intensity is substantially higher among African countries than it is between African countries and the rest of the world. Along similar lines, Iapadre and Luchetti (2009) support that Africa's regional trade is relatively high.

This paper contributes to this literature by focusing on a selection of indicators of trade integration and by reviewing the extensive available literature on these indicators. There is no clear-cut economic definition of trade integration. Balassa (1961) proposed to indirectly define economic integration as a process and a state of affairs. (1) When regarded as a process, it encompasses measures to abolish discrimination between economic units belonging to different national states. (2) When viewed as a state of affairs, it can be represented by the absence of various forms of discrimination between national economies (Balassa 1961). We restrict this definition to trade integration by referring to the abolition of cross-country discrimination in markets for goods and services. Ultimately, for any consumer of intermediate or final goods, integration should result in the absence of economic discrimination between products from different 
countries, including domestic products. This process takes multiple forms, starting with access to foreign markets and the disappearance of trade costs (tariff and non-tariff barriers). In the economy, it translates into the intensification and extensification of trade, as well as greater connection and interdependence between markets for goods and services.

International institutions tend to select indicators such as Trade-to-GDP ratios or the share of intra-regional trade in total trade to qualify Africa's participation in world trade and the level of trade within the region. The economic literature, conversely, has produced vast evidence identifying the biases attached to the use of these simple ratios and supporting other indicators on the basis of gravity equations, price comparisons, direct measures of trade integration, and network analysis.

In this paper, the low quality of data regarding trade and the related phenomenon of informal cross-border trade are not examined. ${ }^{3}$ Rather, this paper focuses on methodology, particularly the measure of trade integration: traditional indicators such as Trade-to-GDP ratios and the share of intra-regional trade in total trade are not correct indicators of trade integration, and when applied to Africa, they give a false impression of how the continent is integrated from the trade perspective. We also demonstrate that the use of one single indicator cannot capture the multiple dimensions and determinants of trade integration.

The remaining part of this paper is organized as follows; Section 2 begins by assessing the conditions for trade integration in Africa with a set of indicators evaluating barriers to trade. Section 3 reviews the whole set of indicators on the basis of trade flow data, ${ }^{4}$ Section 4 concludes.

\footnotetext{
${ }^{3}$ See Traoré and Mitaritonna (2016), Bensassi et al. (2016), or Lesser and Moisé-Leeman (2009).

${ }^{4}$ We do not present price-based methodologies that might be interesting methodologies to gauge integration but are limited empirically in their sectorial, geographical, and time scope of analysis. We also do not present aggregate indicators of globalization since they are based on arbitrary methodological options. Details on these methodologies are presented in Bouët, Cosnard, and Laborde (2017).
} 


\section{Trade Costs Indicators}

Throughout this paper, statistics for 12 regional agreements are provided. The following acronyms are used: ASEAN for Association of Southeast Asian Nations, CEMAC for Communauté Économique et Monétaire des Etats de l'Afrique Centrale, COMESA for Common Market for Eastern and Southern Africa, EAC for East African Community, ECOWAS for Economic Community of West African States, EU for European Union, IGAD for InterGovernmental Authority on Development, MERCOSUR for Mercado Común del Sur, NAFTA for North American Free Trade Agreement, SACU for Southern African 15 Union, SADC for Southern African Development Community and UMA for Union du Maghreb Arabe.

\section{A. Tariffs}

As this paper focuses more on the methodology surrounding trade indicators, our evaluation of tariffs is based on the work conducted at CEPII using the MAcMAP-HS6 database. The database's methodology is explained in Bouët et al. (2008a). We use the most recent version of the MAcMAP-HS6 database (the 2010 version; Guimbard et al. 2012) to construct three tables.

Table 1 indicates that in terms of import duties, Africa is the least open continent in the world; Africa's average import duty on all merchandise is 9.67 percent. Protection is particularly high in the agricultural sector (19.58 percent) compare with in nonagricultural sectors ( 8.30 percent) and in the CEMAC and IGAD trade agreement regimes. However, the average duty faced by African exports is relatively low (2.72 percent) when compared with the duty faced by ASEAN countries (3.90 percent) and Oceanian countries (5.65 percent). Two facts explain this finding. First, many African countries have been granted preferential regimes, particularly with the European Union through the Everything But Arms initiative and with the United States of America through the African Growth Opportunity Act. Second, many African countries' exports mainly consist of energy or mineral products, which benefit from low import duties throughout the world. 
Table 1. Average ad valorem equivalent of import duties

(Continent and regional agreement, 2010, \%)

\begin{tabular}{|c|c|c|c|c|c|c|}
\hline & \multicolumn{3}{|c|}{ Average import duty } & \multicolumn{3}{|c|}{ Average duty faced on exports } \\
\hline & All & Agricultural & $\begin{array}{c}\text { Non } \\
\text { Agricultural }\end{array}$ & All & Agricultural & $\begin{array}{c}\text { Non } \\
\text { Agricultural }\end{array}$ \\
\hline Africa & 9.67 & 19.58 & 8.30 & 2.72 & 9.86 & 1.93 \\
\hline Asia & 5.20 & 19.01 & 3.87 & 3.95 & 14.40 & 3.48 \\
\hline Europe & 2.74 & 13.33 & 1.95 & 4.44 & 16.40 & 3.29 \\
\hline $\begin{array}{l}\text { Latin } \\
\text { America }\end{array}$ & 7.06 & 14.37 & 6.30 & 4.73 & 14.12 & 2.29 \\
\hline $\begin{array}{l}\text { North } \\
\text { America }\end{array}$ & 2.05 & 7.16 & 1.61 & 4.35 & 14.00 & 3.15 \\
\hline Oceania & 2.97 & 2.36 & 3.03 & 5.65 & 20.36 & 1.90 \\
\hline$A S E A N$ & 3.93 & 8.54 & 3.48 & 3.90 & 14.46 & 2.64 \\
\hline CEMAC & 14.57 & 19.50 & 13.91 & 1.08 & 2.59 & 1.01 \\
\hline COMESA & 9.95 & 25.50 & 7.74 & 3.54 & 11.87 & 2.05 \\
\hline$E A C$ & 11.23 & 24.22 & 8.61 & 8.26 & 12.04 & 4.85 \\
\hline ECOWAS & 9.99 & 13.96 & 9.24 & 2.22 & 5.45 & 1.78 \\
\hline$E U$ & 2.25 & 10.63 & 1.68 & 4.92 & 16.73 & 3.67 \\
\hline$I G A D$ & 13.33 & 21.23 & 11.69 & 4.98 & 10.37 & 2.36 \\
\hline Mercosur & 9.47 & 10.37 & 9.38 & 7.41 & 16.76 & 3.08 \\
\hline NAFTA & 2.40 & 9.10 & 1.80 & 3.94 & 13.52 & 2.84 \\
\hline$S A C U$ & 5.53 & 12.77 & 4.73 & 4.07 & 13.93 & 3.00 \\
\hline$S A D C$ & 6.98 & 13.56 & 6.11 & 3.32 & 12.48 & 2.35 \\
\hline$U M A$ & 10.35 & 23.31 & 9.07 & 1.88 & 11.04 & 1.39 \\
\hline
\end{tabular}

(Note) Tariffs are weighted according to the reference group method (Bouët et al. 2008a).

The following acronyms are used: ASEAN for Association of Southeast Asian Nations, CEMAC for Communauté Économique et Monétaire des Etats de l'Afrique Centrale, COMESA for Common Market for Eastern and Southern Africa, EAC for East African Community, ECOWAS for Economic Community of West African States, EU for European Union, IGAD for InterGovernmental Authority on Development, MERCOSUR for Mercado Común del Sur, NAFTA for North American Free Trade Agreement, SACU for Southern African 15 Union, SADC for Southern African Development Community and UMA for Union du Maghreb Arabe.

(Source) MAcMap-HS6 and authors' calculation 
An examination of the average duty applied on imports and faced by exports for each African country confirms the relatively high level of protection in many African countries. ${ }^{5}$ Outside Africa, the average duty applied on imports ranges from 0.00 percent (Hong Kong) to 28.69 percent (Bermuda); however, 88 percent of countries' import duty averages are below the African average (10.50 percent $\left.{ }^{6}\right)$. Some African countries are relatively protectionist (particularly Djibouti and Gambia), whereas others (Lesotho, Mauritius, Mayotte, Namibia, South Africa, and Swaziland) are relatively open.

African countries whose exports mostly consist of petroleum and gas (Algeria, Angola, Chad, and Equatorial Guinea) benefit from a very low average duty on exports. This is not the case for Malawi, for which tobacco and sugar are major exports, and Guinea-Bissau, which exports mainly fish, shrimp, and cashew nuts. On average, African countries benefit from relatively good access to foreign markets in terms of tariffs; more than 52 percent of countries outside Africa face a higher average duty on exports than the African average of 4.80 percent. $^{7}$

When evaluating the average duty imposed on intra-continental trade and trade among countries in the same regional agreement, it is concluded that Africa has the highest average duty on its global intra-continental trade (8.62 percent) and is second only to Asia when considering only agricultural products. Despite the success of certain regional agreements in suppressing duties (CEMAC, EAC, SACU), African countries still impose high duties on trade on one another when compared with the low duties that African exports face globally (2.72 percent). This appears to be a major disincentive for intra-African trade, particularly for agricultural products, which face a 15.23 percent duty inside the continent when compared with 9.86 globally. Protection regarding intraregional agreements is particularly high in ECOWAS, IGAD, and SADC.

Finally, we also assess the importance of export taxes using the database developed by Laborde, Estrades, and Bouët (2013). ${ }^{8}$ This database provides information on ad valorem and specific export taxes by exporter at the HS6 level. These taxes can be an important impediment to exports in some countries, such as Côte d'Ivoire, Cameroon, and Ghana, where their level is equivalent to or higher than the average duty faced on exports. On average, export taxes are lower in Africa relative to other continents.

\footnotetext{
Bouët, Cosnard, and Laborde (2017).

${ }^{6}$ A simple average of national averages

${ }^{7}$ A simple average of national averages.

${ }^{8}$ Bouët, Cosnard, and Laborde (2017).
} 


\section{B. Non-tariff measures}

Non-Tariff Measures (NTMs) make up a substantial part of trade barriers at present. As defined by OECD (Organization for Economic Cooperation and Development), NTMs are measures other than normal tariffs that have the effect of restricting trade between nations. These include measures such as price and quantity control measures, anti-dumping and safeguards, Sanitary and Phyto-sanitary Standards (SPS), Technical Barriers to Trade (TBT), export measures, trade-related investment measures, distribution restrictions, restrictions on post-sale services, subsidies, and measures related to intellectual property rights and rules of origin.

Kee, Nicita, and Olarreaga (2009) estimate ad valorem equivalents of Non-Tariff Barriers (NTBs). ${ }^{9}$ They first estimate the quantity impact of NTMs on imports by regressing imports of each good by each country on a dummy variable indicating the presence of a NTM and on other regressors such as GDP and indicators of comparative advantage. Next, they transform the evaluated quantity impacts into price effects, using import demand elasticities estimated in their earlier study (Kee, Nicita, and Olarreaga 2008).

Calculating the simple average of country average ad valorem equivalents of NTBs for every continent on the basis of this methodology (Table 2), it is concluded that Africa has the highest NTBs on average. However, as already indicated, dispersion is high: there are many African countries with low NTBs. There is a great deal of heterogeneity in these average trade restrictions provided by NTBs, with averages close to 0 percent in Cameroon, Gabon, and Uganda and high averages in Algeria, Côte d'Ivoire, Egypt, Nigeria, Senegal, Sudan, and Tanzania.

\footnotetext{
${ }^{9}$ Their definition of NTBs is slightly different from the definition of NTMs by OECD. According to Kee, Nicita, and Olarreaga (2008), NTBs include price control measures, quantity restrictions, monopolistic measures, and technical regulations.
} 
Table 2. Average ad valorem equivalents of Non-Tariff Measures

(2001 2004, \%)

\begin{tabular}{|l|c|c|}
\hline & All & Agriculture \\
\hline Africa & 15.67 & 20.85 \\
\hline Asia & 13.07 & 22.99 \\
\hline Europe & 6.46 & 28.34 \\
\hline Latin America & 10.49 & 28.11 \\
\hline North America & 7.74 & 24.24 \\
\hline Oceania & 9.73 & 29.11 \\
\hline
\end{tabular}

(Note) The simple averages for aggregation from the HS6 level to the HS2 level of product classification: a tradeweighted average does not change the averages significantly. Ad Valorem equivalents are then weighted according to the reference group method (Bouët et al. 2008a).

(Source) Kee, Nicita, and Olarreaga (2009) and authors' calculation

\section{Other trading costs}

Border measures such as tariffs and NTMs are not the only impediments to international trade. Other trading costs can slow down or even prevent trading across borders. These include high domestic transportation costs, the lack of communication infrastructure, and insufficient access to credit and/or insurance markets.

The World Bank's Doing Business team measures several important dimensions of countries' regulatory environments and provides quantitative indicators on these dimensions, particularly trading across borders (The World Bank 2016). Eleven sets of indicators were selected on the basis of economic research and firm-level surveys investigating the main obstacles to business activity in more than 135 economies. Each indicator is grounded in the study of national regulations; more than 9,600 practitioners and professionals of these regulations in 185 economies provide inputs and verify the entire process.

Doing Business 2016 provides the value for the same eight components of the trading across borders indicator for 51 African countries. Lesotho and Swaziland are the most efficient countries, whereas Congo D.R. may be considered to be the least efficient. In the list of world rankings, African countries are at the tail end, particularly Angola, Cameroon, Congo D.R., Eritrea, Liberia, Nigeria, Sudan, and Tanzania. In Congo D.R., 
it takes 804 hours and costs 2,964 US dollars in documentary and border compliance to import a standard container of auto components. These figures are 1 hour and 0 US dollars for most European countries.

\section{Adding up all trade costs}

With measurements of tariffs, NTM, and other trade costs, it is interesting to compare the relative importance of these different trade barriers. To have every measure in a comparable unit, results from Doing Business on the costs and time for border and documentary compliance are converted into ad valorem equivalents. ${ }^{10}$

Since the costs for border and documentary compliance are computed in Doing Business for the equivalent of a 15-metric-ton container, the total quantity of products exported and imported is computed in a container equivalent unit using quantity data from BACI. Those quantities are then multiplied by the costs per container available in Doing Business, and the result is divided by the corresponding value for total exports and imports from BACI to get an ad valorem equivalent.

The time spent for the shipment of products represents a cost for traders as it results in excess inventory holding, depreciation costs, and even actual spoilage. In order to evaluate the costs associated with the time of border and documentary compliance available in Doing Business, results from Hummels and Schaur (2012) are used. These authors evaluate the cost associated with the time a product spends in transit by computing the time premium in the choice of transportation between air and ocean transit from data on US imports. They find that each day in transit is equivalent to an ad valorem tariff between 0.6 and 2.1 percent and that this figure can go up to as much as 3.1 percent for agricultural products. The times of documentary and border compliance are converted into costs in ad valorem equivalents for all products and for only agricultural products by multiplying the time results from Doing Business by the per day ad valorem equivalents estimates from Hummels and Schaur (2012). The lower bound of 0.6 percent of ad valorem tariff equivalent per day is used for all products, except for the

\footnotetext{
${ }^{10}$ There is no redundancy here. Doing Business makes a distinction between the time and cost (excluding tariffs) associated with documentary compliance and border compliance in the global process of exporting or importing a shipment of goods. The cost defined here does not include the cost associated with the time lost in the procedure but only the direct cost, which is effectively paid in cash by the trader.
} 
3.1 percent used for agricultural products.

With comparable estimates for every trade cost available, they are compared to border protection and added to produce an overall protection indicator by country for exports and imports. Figure 1 displays those results for export costs for all products and for only agricultural products, respectively, for 56 African countries. Figure 2 presents the same results on the import side.

In Figure 1, African countries with the greatest impediments on their exports are Guinea, Madagascar, Sierra Leone, Congo D.R., Liberia and Mauritania. In contrast, Eritrea, Sudan, Niger, Morocco, and Tunisia have the fewest impediments. There is a significant level of heterogeneity across African countries, with ad valorem equivalents of the global export cost ranging from 1 to 78 percent. Export costs appear to be very high in Africa, averaging 17 percent; only 16 percent of the other countries in the world have greater export costs. It is also worth noting the high heterogeneity in the structure of those costs. For example, exports from Guinea, Madagascar, and Sierra Leone are greatly penalized by direct costs for border and documentary compliance, whereas those costs are relatively low for Congo D.R. The share of export restrictions in global export cost is large in Côte d'Ivoire, in particular for agricultural products. When considering the export costs for only agricultural products, we conclude that the countries' rankings change substantively. For example, South Africa has small export costs for all products but is in the top half of the table for agricultural products.

The costs associated with time for border and complementary compliance can be massive impediments to exports for many African economies, taking into account that the lower bound for the estimation of these costs in the case of all products is considered (an ad valorem equivalent of 0.6 percent for each day lost and not the higher bound of 2.1 percent). Concerning agricultural products, there is only one estimate of the ad valorem equivalent of each day (3.1 percent). However, when the time to export/import is high, there are high ad valorem equivalents. In Congo D.R., for example, for agricultural products, border compliance requires 515 hours and documentary compliance requires 698 hours (i.e., 50 days), resulting in a total ad valorem equivalent export tax of more than 156 percent for agricultural products. The costs associated with these shipping times depend a lot on the product considered; however, they represent a massive barrier for trade in edible products. 


\section{Figure 1. Available export costs in ad valorem equivalents}

\section{A. All products}

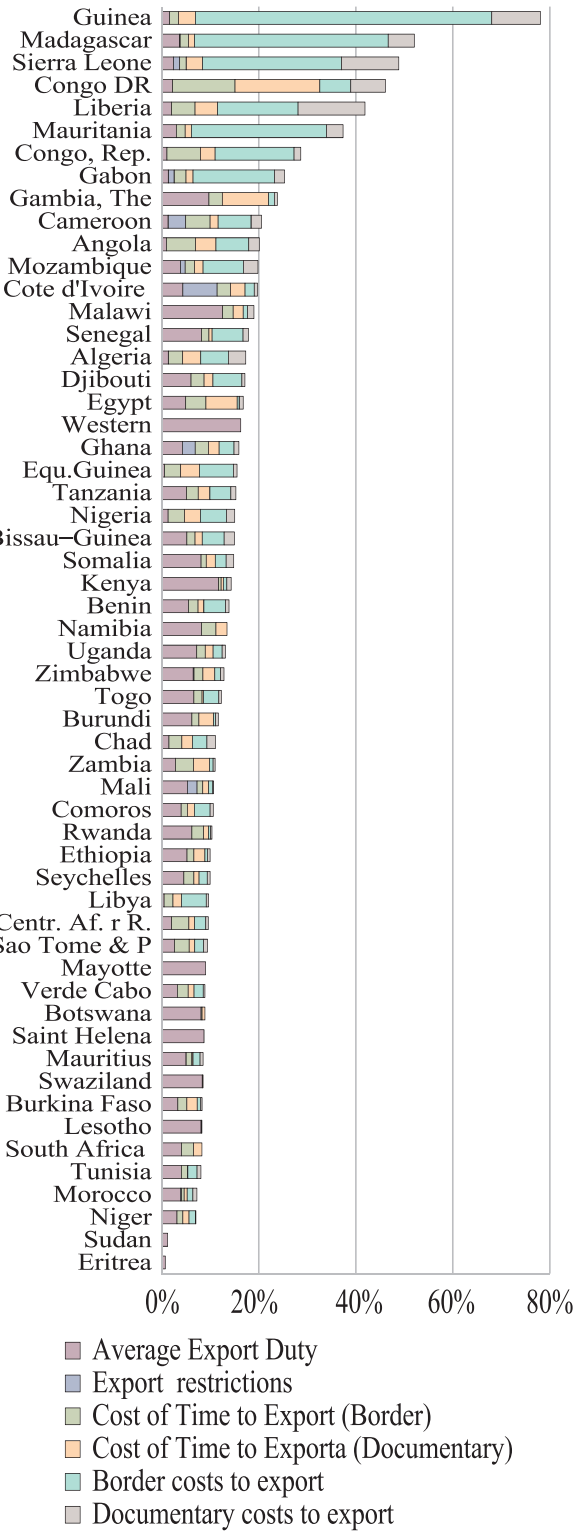

\section{B. Agricultural products}

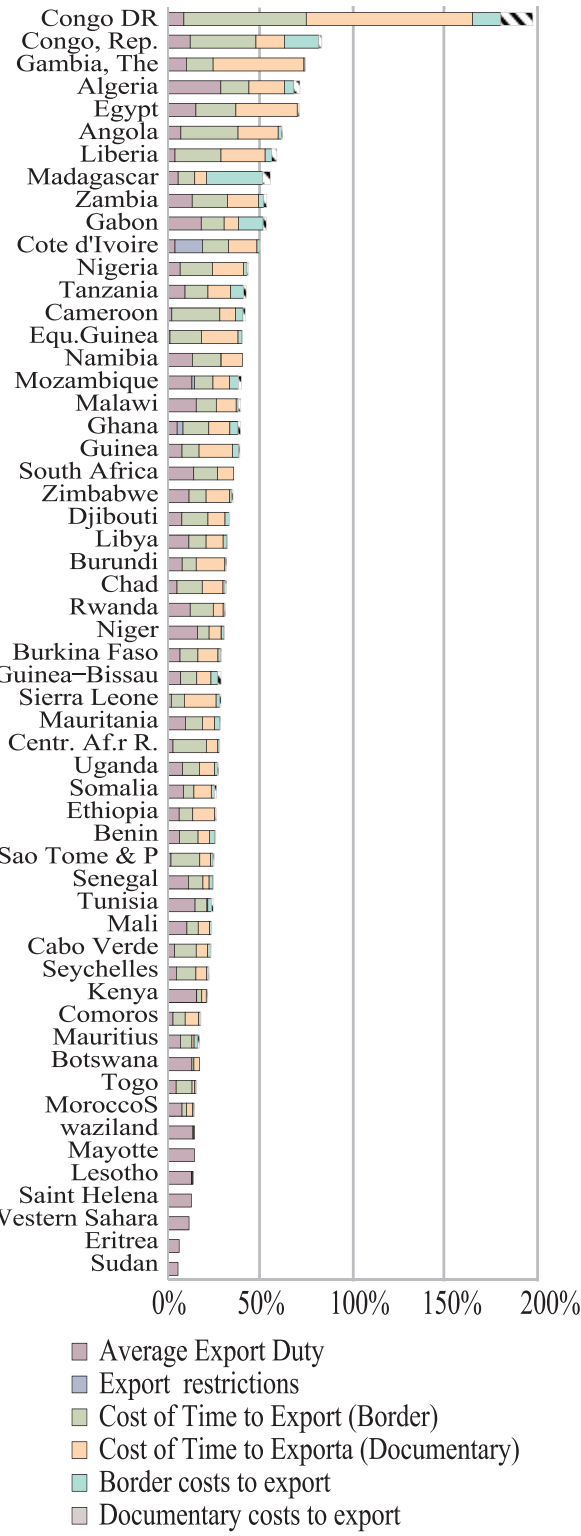

(Source) Authors' calculation using data from BACI, Doing Business (2016), MacMap-HS6 (2010), Kee, Nicita, and Olarreaga (2009), Laborde, Estrades, and Bouët (2013). 


\section{Figure 2. Available import costs in ad valorem equivalents}

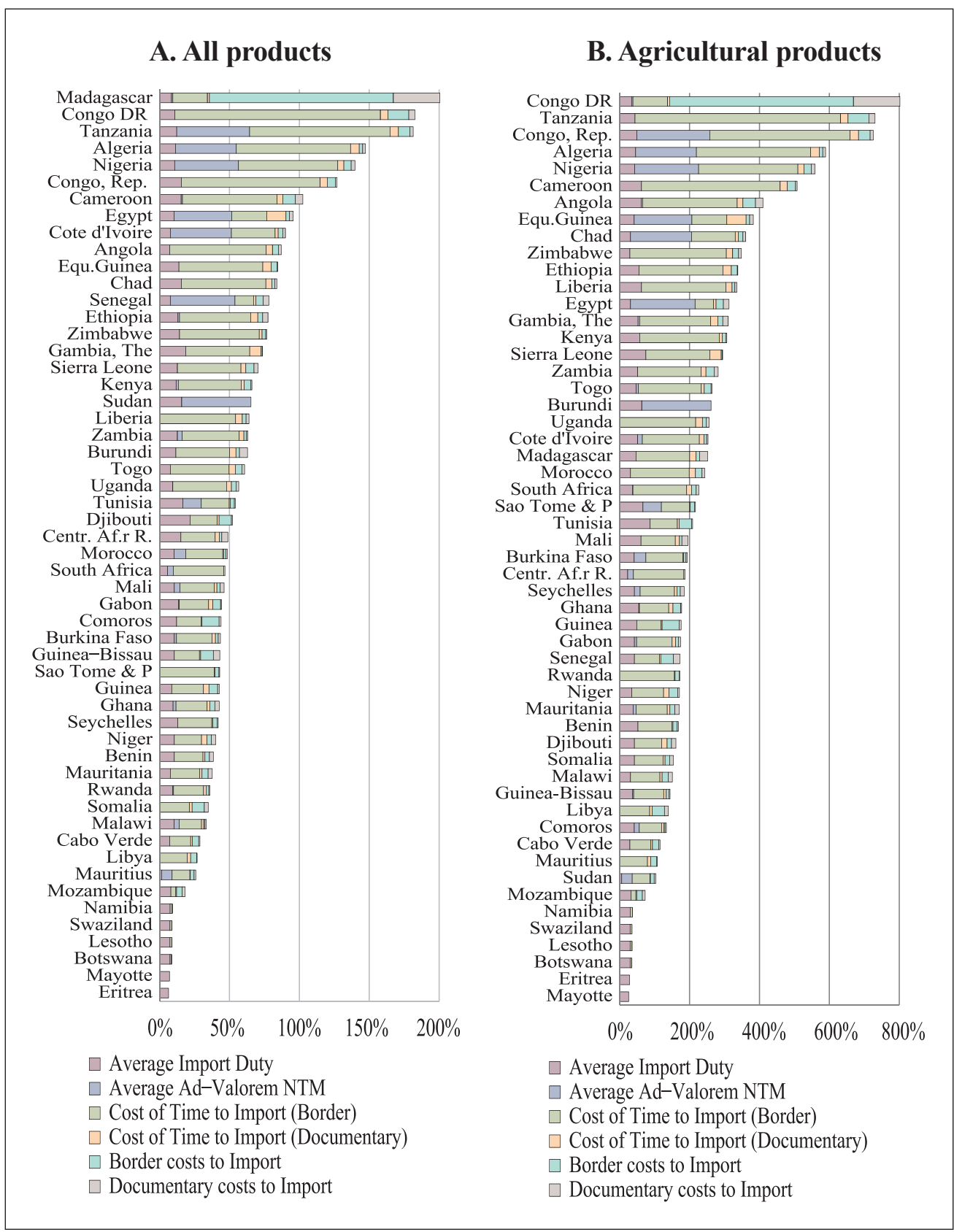

(Source) Authors' calculation using data from BACI, Doing Business (2016), MacMap-HS6 (2010) (www.cepii.fr), Kee, Nicita, and Olarreaga (2009), Laborde, Estrades, and Bouët (2013). 
From Figure 2, it appears that the countries with the highest import costs are Madagascar, Congo D.R., Tanzania, Algeria, Nigeria, and Congo. Same as above, African countries as a whole have high import costs, averaging 60 percent. Outside of Africa, only 8 percent of countries have import costs that top this average. The heterogeneity in the structure of these costs is high as well as is the importance of these costs, with overall costs ranging from 6 percent to 200 percent. The role that NTMs play in some countries, such as Tanzania, Algeria, Nigeria, Sudan, and Egypt, is also important. Madagascar appears to be an outlier, with massive estimates for direct costs associated with border and documentary compliance. The costs associated with time for documentary and particularly border compliance are even more important for imports than they are for exports. Of course, these results have to be considered carefully since these estimations are based on a methodology that evaluates the time premium and has been extrapolated to all commodities. A further analysis could be deepened country by country.

However, from these analyses, we conclude that trading costs in Africa are relatively high, particularly import duties, transportation costs, documentary compliance, and border compliance costs.

\section{Indicators Based on Trade Flows}

This section presents some indicators based on trade flows. Most of the calculations made in this section are based on the BACI world trade database developed by CEPII (Gaulier and Zignago 2010). This database provides bilateral trade values at the HS 6-digit product disaggregation level, covering more than 200 countries $^{11}$ for the period 1995 2012.

\section{A. Trade-to-GDP measures}

The comparison of the gross trade value of a country to some other characteristic,

\footnotetext{
${ }^{11}$ However, some countries remain aggregated as is the case with the Southern African Custom Union (Botswana, Lesotho, Namibia, South Africa, and Swaziland). Depending on the calculation, those regions may either be omitted or the results may be presented for the whole region.
} 
particularly its GDP, is a common way of assessing a country's trade integration. This indicator can be explained as follows: Let $X_{r, s}^{k}$ be the trade flow of product $k$ from country $r$ to country $s$. With the dot indicating a summation, $X_{\dot{r},}$ represents the total exports of country $r$, and $X_{., r}$ denotes the total imports of country $r$. Let $Y_{r}$ be the GDP of $r$. The most intuitive and commonly used indicators for assessing the trade openness of a country or a region are ratios of Trade-to-GDP (Harrison 1996, Brahmbhatt 1998, OECD 2005, Arribas et al. 2006, Samimi et al. 2011, De Lombaerde and Iapadre 2012), such as the following:

$$
T O_{r}=\frac{X_{\dot{r}_{r},}+X_{\cdot, r}}{Y_{r}}
$$

It is possible to construct variants of this indicator, in which the numerator may consist of only exports or only imports or may be divided by 2 to measure a country's average trade flow.

Although these indicators are highly recognized and used for their simplicity, they incorporate some inherent biases that can make their interpretation misleading as follows. (1) Trade is measured in gross terms, whereas GDP only accounts for the value-added produced. Those ratios will be higher in countries engaged in activities that include processing and assembling of traded components. (2) Since GDP includes services, the numerator should include trade in goods and services. However, such indicators are mostly measured on the basis of only trade in goods. Consequently, this ratio will be highly dependent on the orientation of a country's economy (Brahmbhatt 1998, OECD 2005, Mikic 2008, Iapadre and Luchetti 2009). If a country's production is oriented toward activities that are mostly not traded internationally, such as services, this ratio will drop. (3) Those indicators also include some biases related to country size. It is well known that a country with a small population trades relatively more as part of their GDP (Brahmbhatt 1998, OECD 2005, Samimi et al. 2011, Riezman et al. 2013). Therefore, Trade-to-GDP ratios are inversely related to country size. ${ }^{12}$

Consequently, the Trade-to-GDP ratio needs to be carefully used and should not be

\footnotetext{
${ }^{14}$ Anderson and Norheim (1993) provide three potential explanations for the fact that countries with a small population trade relatively more. First, larger countries have potentially more productive resources available and consequently local production is more capable of meeting local demand. Second, in small countries, transport costs and other trading costs are smaller on average, such that foreign products are more competitive in small countries when compared to large countries, with everything else being equal. Third, geographic space may be more or less fragmented. Imagine a world consisting of three countries with equal GDPs and equal trade between each pair of countries. Imagine then that two of these countries merge. In this scenario, the ratio of Trade-to-GDP of this new country is divided by two.
} 
the basis of cross-country comparison (Iapadre and Luchetti 2009). The Trade-to-GDP ratio can be useful when studying the time evolution of trade integration for one country or one region by identifying periods of increasing or decreasing openness. However, this ratio may have a rather chaotic evolution with important variations from one year to another.

To enable easier cross-country comparisons of trade openness, Iapadre and Luchetti (2009) provide a Symmetric Indicator of Relative Openness. Although this indicator does not prevent all biases related to the evaluation of openness via Trade-to-GDP ratios (particularly the differences in the measurement of trade as compared to the measurement of GDP), it does provide a relative symmetric measure, such that this indicator will be equal to zero if the region's degree of openness is equal to the average of the rest of the world. It is computed in the following way:

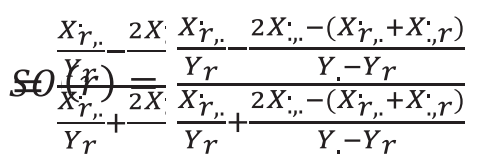

with $Y$. equaling the world GDP. While this indicator is an improvement over simple Trade-to-GDP ratios, because it includes a benchmark, it still contains most of the biases of the simple indicators. As in the Trade-to-GDP ratios, the fact that services are included in the denominator and not the numerator leads to an overestimation of the degree of openness of African economies since these countries produce fewer services than other countries.

In order to tackle some of the issues related to Trade-to-GDP ratios, Arribas et al. (2006) propose a measure of the degree of openness called the corrected degree of openness. This looks only at exports but aims to correct for the domestic bias related to the size of the economy under consideration. To do so, it takes a corrected measure of GDP as the denominator by multiplying it by one minus the weight of the studied economy in the world economy. The denominator is intended to measure the GDP destined for exports, representing a benchmark by which countries would allocate their consumption between domestic and foreign sources according to their weight in the world economy. The theoretical foundations for this correction are debatable; however, it can provide a perspective other than Trade-to-GDP, considering the influence of country size. It is computed in the following way: 


$$
D O(r)=\frac{X_{\dot{r}_{.}}}{\overline{Y(r)}}
$$

where $\hat{Y}(r)$ is the production destined for export estimated by $\hat{Y}(r)=Y r-a r Y r$, and $a_{r}=\frac{Y_{r}}{Y}$ is the weight of economy $r$ in the world economy. Table 3 shows unweighted averages of both indicators by continent. The Corrected Degrees of Openness column reveals that Africa and North America are relatively less open than Asia, South America, and Europe; Oceania is the most open continent.

Table 3. Four indicators of trade openness

(Average year 2011 and year 2013)

\begin{tabular}{|l|c|c|c|c|}
\hline & $\begin{array}{c}\text { Trade-to-GDP } \\
\text { ratio }\end{array}$ & $\begin{array}{c}\text { Trade-to-GDP } \\
\text { without } \\
\text { services ratios }\end{array}$ & $\begin{array}{c}\text { Symmetric indicator } \\
\text { of relative openness }\end{array}$ & $\begin{array}{c}\text { Corrected } \\
\text { degree of } \\
\text { openness }\end{array}$ \\
\hline Africa & 0.8311 & 1.4718 & 0.1235 & 0.2669 \\
\hline Asia & 0.7529 & 2.3461 & 0.1366 & 0.3358 \\
\hline Europe & 0.8882 & 2.7306 & 0.2475 & 0.4061 \\
\hline Latin America & 0.8154 & 2.7543 & 0.1268 & 0.3057 \\
\hline North America & 0.4946 & 2.0981 & -0.0454 & 0.1714 \\
\hline Oceania & 4.7441 & 14.7698 & 0.2509 & 0.5567 \\
\hline
\end{tabular}

(Note) GDP for Gross Domestic Product

(Source) Authors' calculations based on BACI and WDI

To tackle the problem of the different coverage of the numerator and the denominator in Trade-to-GDP ratios, with services included in the GDP but not in trade, we correct this ratio by comparing trade with a measure of GDP excluding services (Table 3). Those ratios are computed using the share of service in the GDP from the World Development Indicator to remove services from the original GDP. Calculating the correlation between Trade-to-GDP ratios with and without services in GDP, it is concluded that the relationship between the two ratios is quite linear. However, there are still a few outliers, proving that in some cases, the choice of ratio matters. Moreover, the share of services in the GDP of African countries is generally smaller than that in the GDP of other regions. Taking Trade-to-GDP ratios without correcting for services may thus overestimate the openness of African countries. 


\section{B. Gravity analysis}

Most trade integration indicators do not explicitly link the observed levels of trade with any determinant. For example, a specific trade indicator such as the average share of regional trade in total trade for all countries in Western Africa cannot completely explain the level of trade integration in this region since trade has many determinants. Trade between $r$ and $s$ may be determined by trade barriers between $r$ and $s$ but also by other determinants such as the intensity of demand in $s$, consumer tastes in $s$, production capacity in $r$, and transportation costs. Thus, it is impossible to conclude from the level of trade between $r$ and $s$ whether actual trade integration between $r$ and $s$ is high or not.

Gravity models offer a theoretical way of explaining trade between two countries. In a simple and symmetric form, a gravity equation relates bilateral trade to each country's size, bilateral trade barriers, and multilateral trade resistance (Anderson and Van Wincoop 2003). Trade resistance consists of bilateral trade barriers between $r$ and $s, r$ 's resistance to trade with all regions, and $s$ 's resistance to trade with all regions. For example, exports from Senegal to Burkina Faso depend on trade barriers applied by Burkina Faso on Senegal's exports, trade barriers applied by all countries and regions in the world on Senegal's exports (the higher these are, the bigger the exports from Senegal to Burkina Faso will be), and trade barriers applied by Burkina Faso on imports from all other countries (the higher these are, the bigger the exports from Senegal to Burkina Faso will be).

Consequently, a gravity model provides a statistical method to estimate potential levels of trade flows based on a series of specific determinants. An interesting approach to estimate the importance of trade resistance was proposed by Hummels (2001) and Anderson and van Wincoop (2003). Letting $X_{r, s, t}$ be the trade between $r$ and $s$ during year $t, Y_{r, t}$ be country $r$ 's GDP for year $t, d_{r, s}$ be the distance between $r$ and $s$, and $\delta_{r}$ be a country's dummy that is equal to 1 if trade includes country $r$ (country fixed effect), it is possible to estimate the equation as follows:

$$
\ln X_{r, s, t}-\ln Y_{r, t}-\ln Y_{s, t}=k+\alpha \ln d_{r, s}+\beta_{r} \delta_{r}+\beta_{s} \delta_{s}+\varepsilon_{r, s, t}-
$$


As explained by Anderson and van Wincoop (2003), this formulation of a Gravity Equation has theoretical foundation ${ }^{13}$, is simple to implement (Ordinary Least Squares can be applied), and does not require any assumption about the internal distance between states or provinces. Multilateral resistance is included since there are country-specific dummies.

Trade data come from BACI (from 2005 to 2013), GDP data from World Development Indicators, and distance data from CEPII. ${ }^{14}$ The coefficient of distance is negative $(\alpha=$ -1.73 ) and significant. In this specification, most country fixed effects' coefficients are significant. Those country coefficients that represent inverses of countries' multilateral trade resistances are shown in Figure 3.

Small Pacific islands have positive coefficients, indicating that these countries trade more than the norm defined by GDP and geographic distance. For African countries, the coefficients of countries' fixed effects are often negative and significant, indicating that these countries trade less than the norm defined by GDP and geographic distance. Compared with the rest of the world, most African countries have a higher resistance to trade, with the exception of coastal western African countries and southeastern African countries. Thus, the gravity equation confirms that African countries are globally undertrading, their actual level of trade is generally less than the norm defined by GDP and distance.

The gravity approach overcomes a lot of the limitations of other indicators. Gravity models are based on theoretical foundations, they offer a benchmarked measure of trade integration, and they do not include any bias related to a country's size or geographic location.

\footnotetext{
${ }^{14}$ The model supposes in particular that (i) all goods are differentiated by place of origin; (ii) each country is specialized in the production of only one good and the supply of each good is fixed; (iii) all consumers have identical and homothetic preferences, with a CES specification; and (iv) trade costs are borne by the exporters. This specification implies that the elasticity of trade to income is unitary.
} 


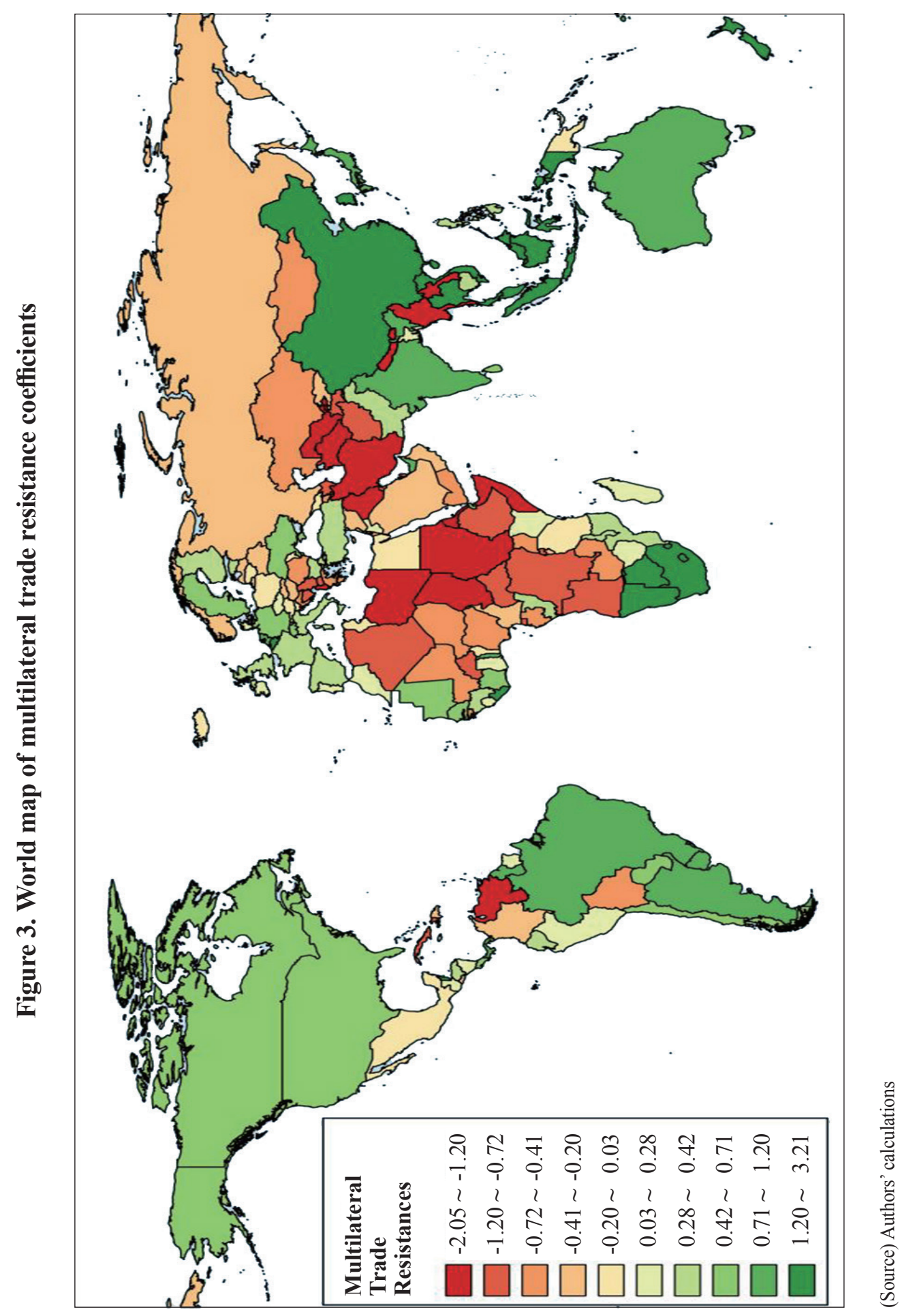




\section{Indicators from the network literature}

Building on the developing field of network analysis, a new set of trade integration indicators has recently been constructed to analyze the global trade network (De Lombaerde and Iapadre 2012, Vinokurov 2010). Network analysis focuses on relationships between countries. Each country is considered to be a node or a vertex connected by trade links or arcs to other parts of the network. Thus, the focus is on the dyad rs. The specificity of this method is to consider the structural dimension of this $d y a d$, or the effect of other countries on the trade relationship between $r$ and $s$. Consequently, those indicators better account for the direct and indirect trade links existing among countries and better describe the pattern of the trade network between centers and peripheries.

The simplest indicator of trade integration and the actual building block of BNA is the degree of a country $(d(r))$. This corresponds to the country's number of direct trade links. A normalized version is the degree of centrality (Kali and Reyes 2006) corresponding to a ratio of this number over the number of nodes including countries or trade partners in the network. Both indicators have a close connection with the notion of extensive margin of trade. A distinction is made between in-degree and out-degree (and in-degree and out-degree centrality) depending on whether the interest is a country's incoming or outgoing trade flow (De Benedictis et al. 2014). Calculated for all countries worldwide between 2006 and 2010, ${ }^{15}$ it can clearly be seen that most African countries trade with a limited number of countries when compared with the rest of the world. African countries imported from 115 countries on average, whereas non-African countries imported from 126 countries. Chad, Central African Republic, Equatorial Guinea, Congo D.R., GuineaBissau, and Somalia appear to have particularly few partners, whereas the Southern African Custom Union is connected to most countries as are Morocco, Algeria, and Nigeria on the import side and Kenya on the export side. In 2010, African countries exported to 105 countries on average, whereas non-African countries exported to 128 countries.

A more global centrality measure is closeness centrality $(C C(r))$, corresponding to the inverse of the average geodesic distance between countries (De Benedictis et al. 2014). This indicator explains both direct and indirect trade links when measuring how well a

\footnotetext{
${ }^{15}$ See Bouët, Cosnard, and Laborde (2017) for detailed results.
} 
country is connected to every other country in the network. Here is how it is calculated:

$$
C C(r)=\frac{N-1}{\sum_{s} D(r, s)}
$$

with $D(r, s)$ being the geodesic distance between the countries $r$ and $s$, which corresponds to the number of steps on the shortest path between $r$ and $s$. If $r$ and $s$ have a trade relationship, this is equal to 1. If $r$ and $s$ have no trade relationship but $r$ and $r$ ' trade and $r^{\prime}$ and $s$ trade, this is equal to 2. Thus, if $r$ has a trade relationship with all other countries, the denominator is the minimum and $C C(r)$ is the maximum at 1. If $r$ has a direct relationship with 176 countries and one indirect trade relationship with the $177^{\text {th }}$, passing through just one another country, the indicator takes the value: $\frac{177}{176+2}=\frac{177}{178}=0.9944$.

Indirect trade relations can be particularly important due to the development of global value chains in which some products are imported and then re-exported to a third country, directly or after processing.

Table 4 indicates the values of averages by continent of In- and Out-Closeness Centrality. Even if this indicator accounts for indirect trade links, the picture remains unchanged: Africa still appears to be poorly connected in the world trade network.

\section{Table 4. In and out closeness centrality}

(Averages by continent, 2010)

\begin{tabular}{|l|c|c|}
\hline & Out-closeness centrality & In-closeness centrality \\
\hline Africa & 0.726 & 0.748 \\
\hline Asia & 0.792 & 0.777 \\
\hline Europe & 0.928 & 0.890 \\
\hline North America & 0.746 & 0.752 \\
\hline Oceania & 0.660 & 0.670 \\
\hline South America & 0.784 & 0.770 \\
\hline World & 0.790 & 0.784 \\
\hline
\end{tabular}

(Source) De Benedictis et al. (2014) and authors' calculation

In-Degree and Out-Degree do not consider the value of trade flows. Taking these flows into account, it is possible to calculate In-Strength and Out-Strength indicators, which look at the value of each importing or exporting flow. A weight is attributed to 
each trade link, usually corresponding to the value of exports, imports, or total trade on each trade link. Therefore, it is possible to calculate the strength centrality corresponding to the weighted counterpart of the degree centrality (De Benedictis et al. 2014). This indicates the average flow of exports. In 2010, the world average flow of exports (465.0 million US dollars) was more than seven times greater than the African average flow of exports (65.3 million US dollars). In 2010, the world average flow of imports (464.9 million US dollars) was more than seven times greater than the African average flow of imports (63.2 million US dollars). Both indicators have a close connection with the notion of intensive margin of trade. It is possible to consider total trade instead of either exports or imports. Normalized versions of these indicators correspond to trade share in terms of exports or imports. Africa's global trade share is only 3.47 percent for exports (Normalized Out-Strength) and 3.36 for imports (Normalized In-Strength) when compared with 40.02 percent and 34.93 percent, respectively, for Asian countries and 6.12 and 6.01, respectively, for Latin American countries. This emphasizes the small position that Africa has in world trade.

Closeness centrality evaluates the number of countries' direct and indirect trade links in an effort to measure how well a country is connected to every other country in the global trading network. However, trade links are unweighted and consequently give the same weight to a direct or indirect connection with a big trading partner as well as a small one. De Benedictis et al. (2014) provide a weighted equivalent to the closeness centrality, whereas Djikstra (1959) provides an algorithm that defines a weighted path as a combination of two elements: the minimum number of trading partners between $r$ and $s$ and the bilateral flow at each step.

De Benedictis et al. (2014) provide Weighted Closeness Centrality Indicators for 178 countries for the period 2006 2010. This indicator is complementary to Binary Closeness Centrality as it focuses on the importance of the links between countries rather than their number. These indicators again reveal the weak integration of Africa in the global trading network, particularly on the import side. In 2010, the average Weighted In- and Out-Closeness indicators were 0.27 and 0.51 in Africa when compared with 0.31 and 0.66 , respectively, for the rest of the world. The calculation of these indicators confirms Africa's small role and weak integration in the global trading network. 


\section{Diversification indices}

The quality of a country's trade integration also depends on its diversification. Greater diversification in the number of trade partners and in the number of traded products can be associated with better integration, as well as with better resilience, just in case one of those markets breaks down.

\section{Geographic diversification indices}

One of the problems with indicators based on Trade-to-GDP ratios is that they completely disregard the geographic dimension of trade and the number of a country's trade partners. Therefore, a number of diversification indicators of trade links are often used to complete the analysis of trade openness. For this purpose, De Lombaerde and Iapadre (2012) use the number of Equivalent Markets, an indicator that corresponds to the inverse of Herfindahl's index. This indicator computes the number of equivalent markets of the same size that would give the same degree of diversification in trade partners as the one actually observed. It is defined as follows:

$$
E M(r)=\frac{1}{H(r)}
$$

with $H(r)$ being the Herfindahl concentration index (OECD 2005), which is calculated as follows:

$$
H(r)=\sum_{s}\left(\frac{X_{\dot{r}, s}+X_{s, r}}{X_{r_{r},}+X_{, r}}\right)^{2}
$$

Bouët, Cosnard, and Laborde (2017) calculate the average number of equivalent markets by country for the period 2009 2013. Most African countries appear to be well diversified in their trading partners, particularly Egypt $(\mathrm{EM}=29)$ and the Southern African Custom Union (24). Some African countries remain very dependent on a limited number of other countries; this is the case for most Central African countries, particularly Liberia (EM = 3.5), Chad (3.3), and South Sudan (1.6).

One issue with these indicators is that they compare the actual distribution of trade flows with an equi-distribution benchmark that does not explain the actual size of every potential partner. Therefore, there is no difference between a situation in which a 
country trades largely with a major trading country and a situation in which a country is highly dependent on a relatively small trading country. In order to overcome this issue, De Lombaerde and Iapadre (2012) suggest the use of a benchmark based on the weight of each commercial partner in world trade. For this purpose, they use the FingerKreinin index of similarity, which they name, in that context, the Global Geographic Diversification Index (GGDI). This evaluates the distance between the distribution of one country's trade and the distribution of trade in the rest of the world as follows:

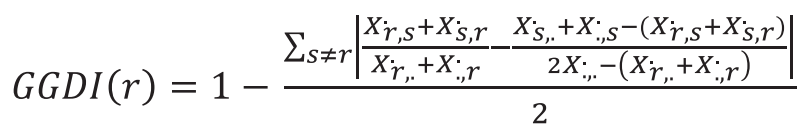

If a country $r$ has exactly the same geographic allocation of its trade as the worldwide distribution of trade, each term in absolute value is equal to 0 and the index is equal to 1. The more the country's geographic allocation of trade differs from the worldwide distribution of trade, the smaller the index. Bouët, Cosnard, and Laborde (2017) calculate GGDI for countries worldwide for the period 2009 2013. African trade appears poorly diversified when compared with the rest of the world. Taking countries individually, the picture can change quite substantially; now, the least diversified countries are Somalia $(G G D I=0.24)$ and Guinea-Bissau (0.33).

\section{Sectorial diversification indices}

To examine product diversification as the extensive dimension of trade integration, a first and simple indicator of product diversification is the number of products traded. Some similar indices as the one used for geographic diversification can also be computed. For example, the number of Equivalent Sectorial Markets $(\operatorname{ESM}(r))$ measures the number of equivalent products of the same size that would give the same degree of diversification in products as the one actually observed as follows:

$$
\operatorname{ESM}(r)=\frac{1}{\sum_{k}\left(\frac{X_{r_{,}}^{k}+X_{, r}^{k}}{X_{\dot{r}_{,},}+X_{: r}}\right)^{2}}
$$

Again, this indicator does not explain the actual size of every potential partner. Figure 4 displays an average Global Sectorial Diversification Index (GSDI). This is the sectorial 


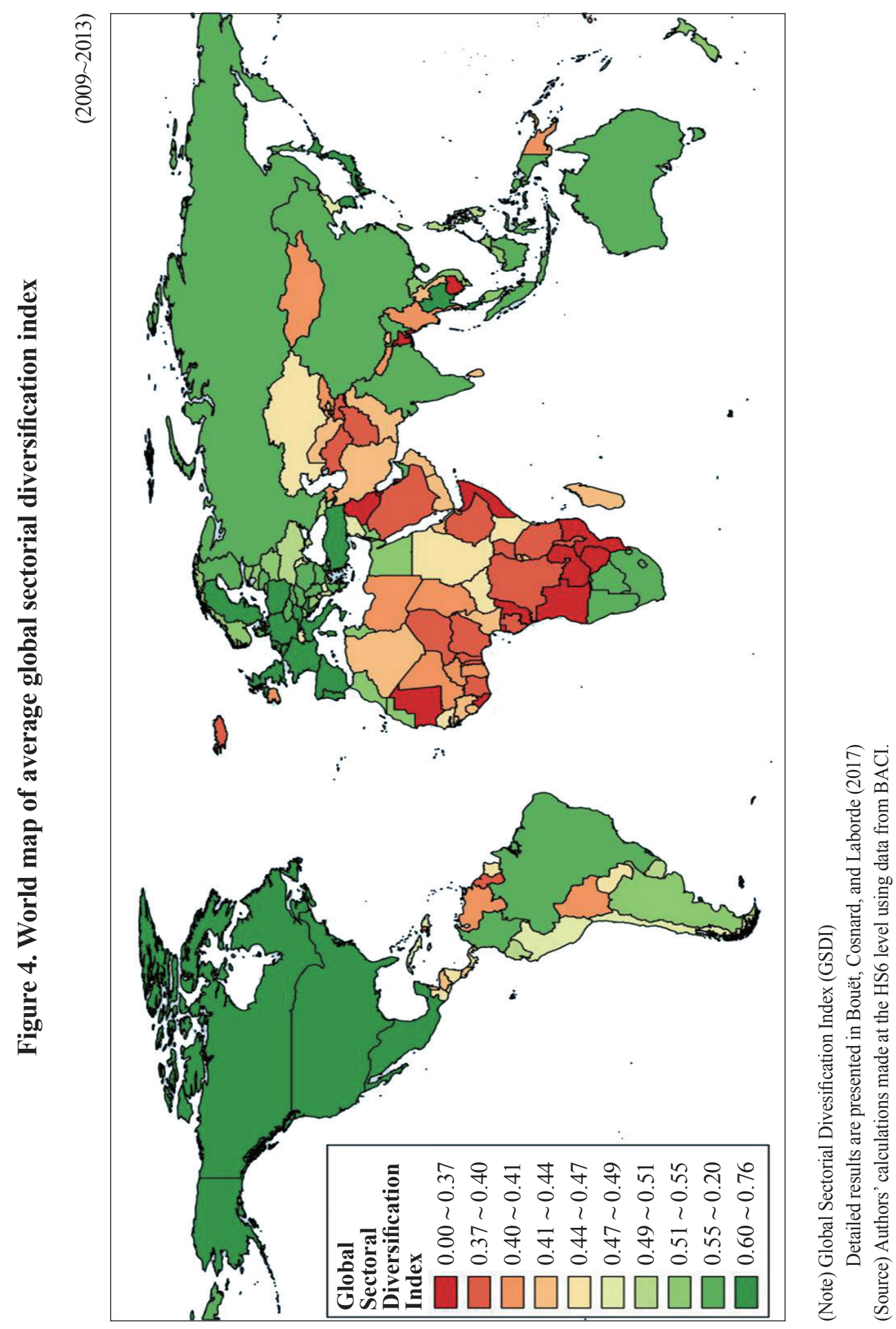


equivalent of the GGDI, measuring the distance between the sectorial distribution of a country's total trade and the sectorial distribution of trade in the rest of the world. It is represented as follows:

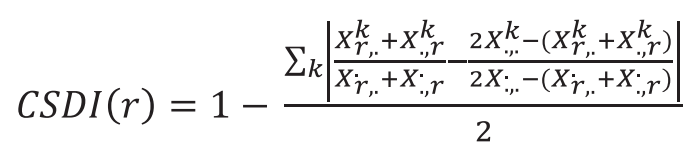

The revealed low diversification in the number of products traded by African countries can be highlighted as an explanation for the region's weak trade integration with the rest of the world.

\section{E. Regional indicators}

Just as with global trade integration, regional trade integration can be evaluated using trade flow data. The simplest and most used indicator of regional integration is the share of intra-regional trade in a region's total trade. However, the use of trade shares as an indicator of regional trade integration ${ }^{16}$ is clearly misleading, both for crossregion comparisons as well as for time-series comparisons, since trade shares depend not only on the degree of integration but also on other factors, such as geography, competitiveness, and economic activity (OECD 2005, Iapadre and Luchetti 2009) as follows: (1) An increase in intra-regional trade shares can in fact be due to closer regional integration. However, it can also be the result of either a loss of competitiveness in international markets (Walkenhorst 2013) or more dynamic activity within the region than outside the region (procyclical bias). (2) Trade shares are highly influenced by geography. For a given total regional space and a given amount of trade, this ratio increases with the number of states within the region. (3) Intra-regional trade shares also depend on the size of the countries within the region. The more fragmented a region is, the more intra-regional trade is recorded and the more this share rises (Walkenhorst 2013, Iapadre and Luchetti 2009, Plummer et al. 2010). (4) For a given area and number of states, this indicator decreases with increasing trade along with the rest of the world. Therefore, this indicator lacks a proper benchmark for it to be used as a measure of

\footnotetext{
${ }^{16}$ Intra-regional Trade-to-GDP ratios can also be used for this application.
} 
regional integration (Hamanaka 2015).

To tackle some of the issues and limitations discussed above, a number of refined trade-based indicators have been developed. The first of these indicators is the IntraRegional Trade Intensity index $\left(I R T I_{R}\right)$ that corresponds to the ratio of the intra-regional trade share of region $R$ and its share in world trade (Iapadre and Luchetti 2009, Plummer et al. 2010). When compared with simple trade shares, this sets the shares in world trade as a benchmark for comparison (Hamanaka 2015). Letting $\alpha_{i}$ be the share of country $i$ in world trade, the intra-regional trade intensity index is defined by the following:

$$
I R T I_{R}=\frac{S I T_{R}}{\alpha_{R}}=\frac{\frac{2 \cdot \sum_{r \in R} \sum_{s \in R} X_{r, s}}{\sum_{r \in R}\left(X_{\dot{r}_{,}}+X_{\cdot, r}\right)}}{\frac{\sum_{r \in R}\left(X_{\dot{r}_{,}}+X_{\cdot, r}\right)}{2 \cdot X_{:, .}}}
$$

This indicator defines a norm for the share of regional trade in the total trade of region $R$ : region $R$ 's weight in world trade. If this indicator is equal to 1 , region $R$ 's trade is considered to be neutral from a geographical perspective; its share of regional trade in its total trade is equal to its share of trade in world trade. If this indicator is greater (less) than 1, its trade is more (less) oriented within the region.

Correspondingly, an Extra-Regional Trade Intensity index $(\operatorname{ERTI}(R))$ can be computed as follows:

$$
E R T I_{R}=\frac{1-S_{R} T_{R}}{1-\alpha_{R}}=\frac{1-\frac{2 \cdot \sum_{r \in R} \sum_{s \in R} X_{\dot{r}, S}}{\sum_{r \in R}\left(X_{\dot{r}_{r},}+X_{:, r}\right)}}{1-\frac{\sum_{r \in R}\left(X_{\dot{r}_{, .}}+X_{:, r}^{\prime}\right)}{2 \cdot X_{:, .}}}
$$

As shown by Iapadre and Luchetti (2010), this intra-regional trade intensity index still incorporates a number of statistical biases: (1) It has a gigantic problem (Hamanaka 2015) in that if the region of interest is important, the evolution of its trade also affects the world's total trade. Thus, if regional trade has a high bias toward itself, the indicator poorly reflects this as this bias will be included in the world's benchmark. (2) It has a range variability problem (Iapadre and Luchetti 2009, Hamanaka 2015). Its maximum value depends on the region's total trade, which could bias cross-regional and intertemporal comparisons. (3) It has a range asymmetry problem (Iapadre and Luchetti 2009). The range below the threshold value of 1 (geographic neutrality) is much smaller (0 to 1$)$ than the range above the threshold value (1 to infinity). (4) Finally, it has a 
dynamic ambiguity problem as in some particular cases, both intra- and extra-regional trade intensity can move in the same direction (Iapadre and Luchetti 2009).

To overcome some of these biases, Iapadre and Luchetti (2009) propose a regional trade introversion index. This is based on modified intra- and extra-regional intensity indices $(\operatorname{MIRTI}(R)$ and $\operatorname{MERTI}(R))$, for which intra-regional trade shares are compared with the region $r$ 's share in trade with the rest of the world $(R O W)$. Taking the rest of the world as the benchmark instead of the whole world overcomes the gigantic problem and the range variability problem mentioned by Hamanaka (2015). Therefore, these indices are defined as follows:

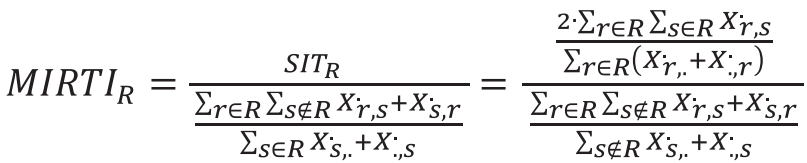

$$
\begin{aligned}
& M E R T I_{R}=\frac{1-S I T_{R}}{1-\frac{\sum_{r \in R} \sum_{S \notin R} X_{r, S}+X_{S, r}^{\prime}}{\sum_{S \notin R} X_{S_{,,}}^{\prime}+X_{;, s}^{\prime}}}
\end{aligned}
$$

Figure 5. Regional trade introversion index by continent

(1995 2013)

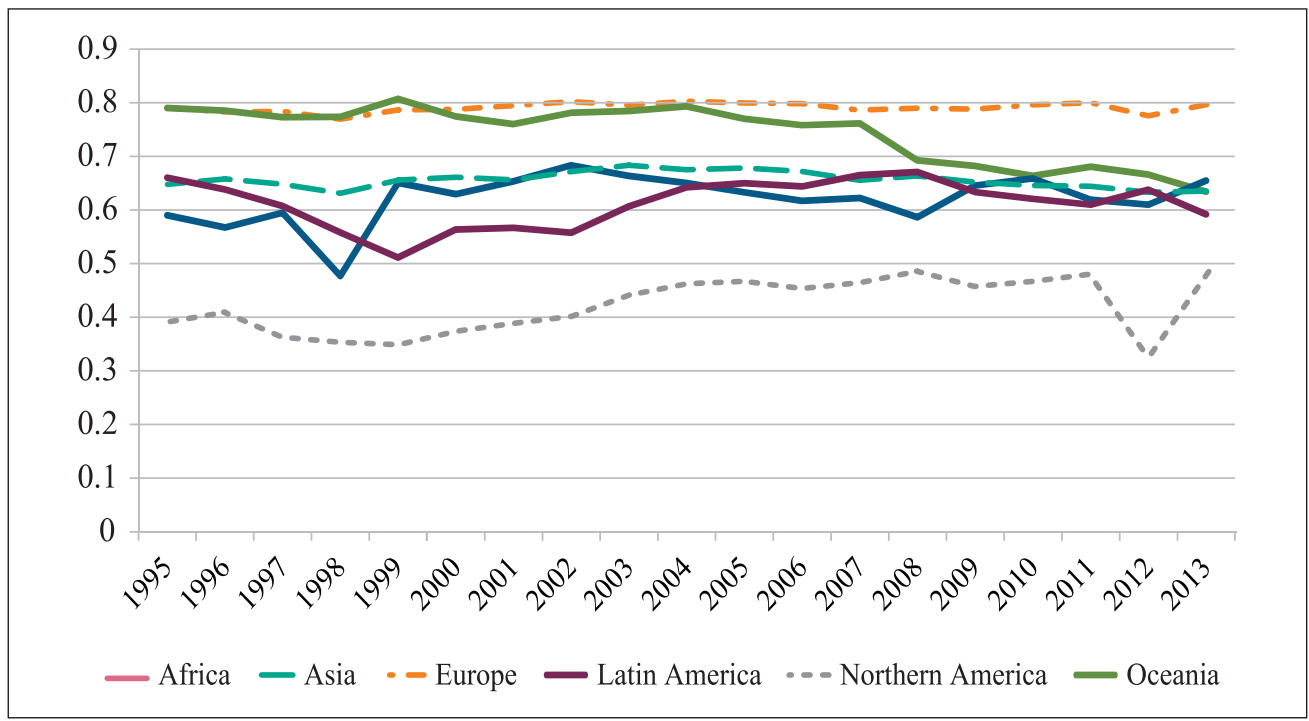

(Source) Authors' calculations 
The regional trade introversion index $(R T I(R))$ is then presented by the following:

$$
R T I_{R}=\frac{M I R T I_{R}-M E R T I_{R}}{M I R T I_{R}+M E R T I_{R}}
$$

This indicator measures the intensity of regional trade introversion. It is symmetric and independent from the size of the region and only increases if intra-regional trade grows more quickly than extra-regional trade (Iapadre and Luchetti 2009, Hamanaka 2015). With this indicator, contrary to the regional trade share, cross-regional comparisons are possible. Positive (negative) signs mean that a region is more (less) introverted than extraverted.

Figure 5 indicates the evolution of regional trade introversion indexes by continent during the period 1995 2013. In 2013, the most introverted continent was Europe. Oceania saw a decline in the indicator during this period, meaning that it experienced growing trade extraversion. Africa appears relatively introverted, ranking second among the six continents in 2013. Examining regional trade introversion ndexes by African RTAs during the period 1995 2013, African RTAs appear relatively introverted, the introversion in Union du Maghreb Arabe (UMA) is a level below though.

The use of the share of regional trade in total trade has many drawbacks, such as no benchmark, bias related to the degree of geographic fragmentation, and no theoretical foundations, among other concerns. However, this indicator is still frequently used by policymakers and national and international institutions. The construction of the regional trade introversion index is simple and corrects many biases attached to the share of regional trade in total trade. ${ }^{17}$

\section{F. Indicators of trade in value-added content}

The rapid development of global value chains and trade in intermediate consumption has significantly changed the world trading structure. Where sectorial specialization was once observed, we now see the development of specialization in tasks with the

\footnotetext{
${ }^{17}$ Similar indicators can be calculated for measuring the introversion of a country with respect to a region.
} 
fragmentation of production chains across the world (World Trade Organization 2010). This fundamentally changes the notion of country of origin on which most statistics are based (World Trade Organization 2010, OECD 2005), raising some new issues regarding the measurement of trade and trade integration.

Trade statistics are usually measured in gross terms, implying a double counting of intermediate consumption that crosses multiple borders (Koopman et al. 2010). Therefore, it is increasingly important to pay closer attention to the value-added content of trade and to develop new indicators for this purpose. Such indicators will be particularly useful for the study of trade integration so as to uncover the place and the importance of each country in Global Value Chains (GVC).

Moreover, these indicators provide a better understanding of the relationship between a country's trade and its economy or the other way around. In other words, by examining the transfers of value-added items, countries that are primary producers, intermediate transformers, trade hubs, or final consumers can be better identified. This can shed light on the results from the other indicators presented so far because the influence that an industrial orientation could have on those indicators has already been highlighted.

The World Trade Organization (2010) presents three main methods for the measurement of trade in value-added goods: (1) direct measurement at the company level; (2) measurement through standard trade statistics; and (3) indirect measurement through input-output tables.

These three techniques require high-quality data, however, available data are generally limited in their time and space coverage. The comparison between the value of intermediate imports and gross output (Hummels et al. 2001) could be a first estimate. Nevertheless, some issues appear when intermediate consumption crosses several borders. The use of Inter-Country Input-Output (ICIO) tables thus appears to be the most suitable technique although the database used for this purpose generally does not cover every year (World Trade Organization 2010).

The literature on the decomposition of trade in value-added goods through ICIO databases has developed significantly in recent years. Koopman et al. (2014) provide the first full decomposition of a country's gross exports into value-added components by source and other double-counted terms. Borin and Mancini (2015) extend this framework to decompose gross trade at the bilateral level. Those terms make it possible to calculate various indicators, including backward integration and forward integration (African Development Bank et al. 2014) or vertical specialization indicators inspired from the work of Hummels et al. (2001), Daudin et al. (2011), and Johnson and Noguera (2012). 
Vertical specialization occurs when (1) a good is produced in two or more sequential stages; (2) two or more countries provide value-added components during the production of the good; (3) at least one country uses imported inputs in its stage of the production process, and some of the resulting output must be exported. (Hummels et al. 2001, p. 76).

Regarding the results that these indicators give for Africa, Johnson and Noguera (2012) report a relatively high ratio of domestic value-added content in gross exports. This confirms the low participation of Africa in vertical trade shown in Daudin et al. (2011). Using calculations from the EORA database, African Development Bank et al. (2014) and Allard et al. (2016) analyze backward and forward integration in GVC, which are evaluated respectively by the shares of foreign value-added content in the export of a country and the share of domestic value-added content that is then re-exported by the destination country.

Allard et al. (2016) report that SSA countries are located at the beginning of GVC, with a share of foreign value-added content (backward integration) representing only 15 percent of their exports and a high share of their exports being used then as intermediate consumption in other regions of the world (forward integration). The authors notice, however, high heterogeneity across African countries in this situation.

African Development Bank et al. (2014) highlight Africa's low but growing participation in GVC, with a share in the world trade in value-added content that grew from 1.4 percent to 2.2 percent between 1995 and 2011. However, they show that relative to its own level of trade in value-added goods, Africa is relatively well integrated in GVC. Measuring integration in GVC as the share of forward and backward integration in total value-added exports, Africa ranks third behind Europe and Southeast Asia. The study confirms that Africa acts principally as a commodity producer for the rest of the world because a great deal of its integration consists of forward integration. Nevertheless, the authors note that the growth of backward integration is much quicker than that of forward integration. At the regional level, East Africa is shown to be the most successful in developing regional value chains. Both African Development Bank et al. (2014) and Allard et al. (2016) underline the actual and potential role of South Africa in the development of regional value chains in southern Africa.

Cosnard and Laborde (forthcoming) compute a new set of trade in value-added indicators inspired from OECD's TiVA database and the decomposition of gross exports from Koopman et al. (2014). Based on the GTAP database, it provides results for a number of African countries. Although its coverage is not as wide as the EORA database, the GTAP database has been designed for trade analysis and can be expected to provide 
more reliable results.

Koopman et al. (2014) decompose gross exports into nine components called KWW1 to KWW9:

- KWW1: foreign value-added in exports of intermediate goods,

- KWW2: foreign value-added in exports of final goods,

- KWW3: domestic value-added in direct final goods exports,

- KWW4: domestic value-added in intermediate exports absorbed by direct importers,

- KWW5: domestic value-added in intermediate goods re-exported to third countries,

- KWW6: domestic value-added in intermediate exports reimported as final goods,

- KWW7: domestic value-added in intermediate inputs reimported as intermediate goods and finally absorbed at home,

- KWW8: double-counted value-added originally produced at home in intermediate exports,

- KWW9: double-counted value-added originally produced abroad in intermediate exports.

This decomposition of gross exports provides important information for the characterization of a country's trade and the evaluation of its integration by showing the importance of exports of intermediate goods relative to final goods. Backward integration is noticed in the shares of foreign value-added in exports. Altogether, this methodology disentangles a country's place in GVC.

When examining African countries, heterogeneity is again observed. Concerning backward integration (KWW1 and KWW2), foreign value-added represents less than 10 percent of the exports of Botswana, Burkina Faso, and Nigeria, reflecting these countries' early position in GVC. Conversely, Benin and Togo, two entrepôt economies, have gross exports composed of more than 30 percent foreign value-added content. The decomposition of gross exports also shows that these latter countries reimport nearly nothing of the value-added content they export. This is usually characteristic of a more downstream situation in GVC. However, as the content of foreign value-added items in exports appears to be low for most of these countries, it could be supposed that it may reflect the low activity of African countries in the design of processed products, as well as a certain incapacity to purchase the more highly processed products made from their value-added contributions. 


\section{Figure 6. Gross exports of value-added content}

(Origin and destination, 2011)

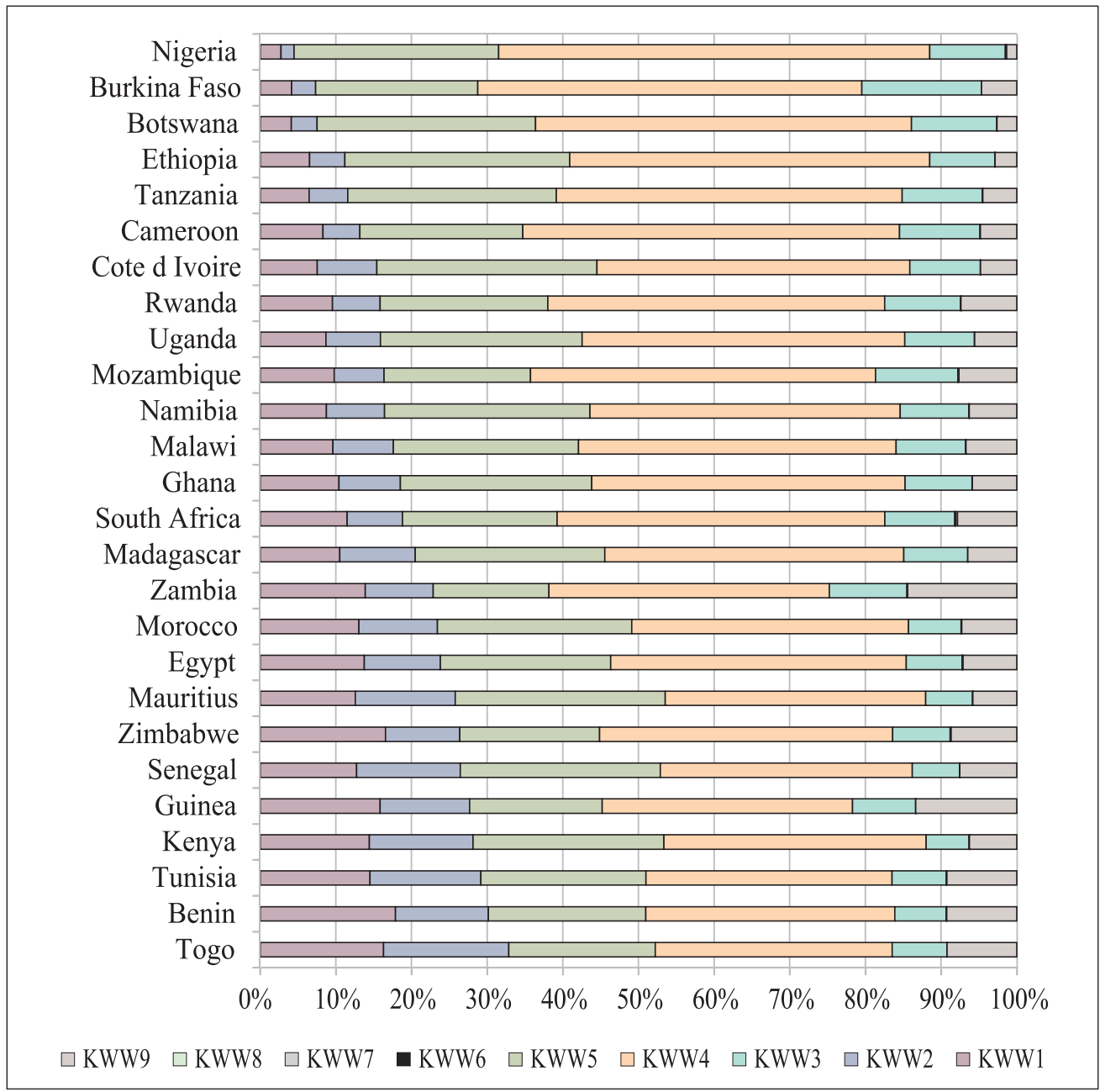

(Note) KWW1: foreign value-added in exports of intermediate goods

KWW2: foreign value-added in exports of final goods

KWW3: domestic value-added in direct final goods exports

KWW4: domestic value-added in intermediate exports absorbed by direct importers

KWW5: domestic value-added in intermediate goods re-exported to third countries

KWW6: domestic value-added in intermediate exports reimported as final goods

KWW7: domestic value-added in intermediate inputs reimported as intermediate goods and finally absorbed at home

KWW8: double-counted value-added originally produced at home in intermediate exports

KWW9: double-counted value-added originally produced abroad in intermediate exports

(Source) Cosnard and Laborde (forthcoming) 
The data and studies available are still scarce for the analysis of African integration in light of trade in value-added indicators. However, this research already appears to be a powerful tool for understanding both Africa's place in world trade and how Africa currently uses and may develop its trade in terms of economic characteristics.

\section{Conclusion}

This paper has reviewed the literature on methodologies designed to measure trade integration focused on the measurement of Africa's trade integration. The authors demonstrate that many indicators are misleading, particularly simple indicators such as Trade-to-GDP ratios or share of regional trade in total trade. In addition, with regard to some purely mathematical biases, these indicators are misleading because there are many other determinants of trade in addition to trade barriers, including economic size, geographic distance, consumer tastes, infrastructure, and institutional arrangements. Regarding these determinants, some more refined indicators that incorporate related benchmarks are useful in assessing the normality of a country's trade level.

From a methodological perspective, the key message of this paper is that there is not one single indicator that can capture a country's level of trade integration correctly. For those seeking to evaluate trade integration, we therefore recommend building a diagnosis on the basis of a set of indicators, as diverse and as complementary as possible, since diverse data may provide various and complementary messages.

As far as Africa is concerned, this study provides evidence of the region's globally weak trade integration. Africa appears to be globally under-trading, as shown by gravity indicators. Africa has a peripheral position in the world trade network and is poorly connected to the rest of the world. Using indicators of trade in value-added products, it is shown that Africa also plays a small role in GVC although its participation is relatively

\footnotetext{
*Acknowledgements: This work was undertaken as part of the CGIAR Research Program on Policies, Institutions, and Markets (PIM) led by the International Food Policy Research Institute (IFPRI). Funding support for this study was provided by US AID and the CGIAR Research Program on Policies, Institutions, and Markets. The opinions expressed here belong to the authors and do not necessarily reflect those of PIM, IFPRI, or CGIAR. The authors thank the participants of a WTO seminar (June 10, 2016) for their helpful comments and suggestions, in particular Hubert Escaith, Joseph Glauber, Lee Ann Jackson, Joachim Jarreau, and Fousseini Traoré. Running title: trade integration in Africa.
} 
good when compared with its overall trade. Africa appears to be mainly a producer of primary commodities that are then used for processing in other parts of the world. From the perspective of trade diversification, African countries have relatively good geographic diversification and do not seem to depend largely on a single country. However, they do display very weak product diversification as their trade seems to rely on a limited number of key commodities. It is finally concluded that intra-regional trade in Africa is relatively high and not relatively low as is often stated.

This conclusion, which is supported by more complex indicators, is in opposition to the previous conclusions drawn by several international institutions that have based their analysis on a cross-region comparison of the share of regional trade to total trade. The low share of regional trade to total trade in Africa seems to reflect other determinants of trade, particularly the low level of economic activity within the region.

Received 6 July 2017, Revised 25 September 2017, Accepted 23 October 2017

\section{References}

African Development Bank, OECD, and United Nations Development Programme. African Economic Outlook 2014 : Global Value Chains and Africa's Industrialisation, Éditions OCDE, Paris, 2014.

Allard, Céline, Jorge Canales Kriljenko, Jesus Gonzalez-Garcia, Emmanouil Kitsios, Juan Trevino, and Wenjie Chen. Trade Integration and Global Value Chains in SubSaharan Africa In Pursuit of the Missing Link. International Monetary Fund, 2016.

Anderson, James E., and Eric van Wincoop. "Gravity with Gravitas: A Solution to the Border Puzzle.” The American Economic Review 93 (2003): 170-192.

Anderson, Kym, and Hege Norheim. "From Imperial to Regional Trade Preferences: Its effect on Europe's Intra- and Extra-regional Trade" Weltwirtschaftliches Archiv 129 (1993): 78-102. 
Arribas, Iván and Pérez, Francisco and Tortosa-Ausina, Emili. "Measuring International Economic Integration: Theory and Evidence of Globalization." University Library of Munich MPRA Paper 16010 (2006).

Balassa, Bela. The Theory of Economic Integration, George Allen and Unwin Ltd, 1961.

Ben Barka, Habiba. "Border posts, checkpoints, and intra-African trade: challenges and solutions.” African Development Bank, Chief Economic Complex (2012).

Bensassi, Sami, Joachim Jarreau, and Cristina Mitaritonna. "Determinants of Cross Border Informal Trade: the case of Benin.” Washington DC: International Food Policy Research Institute (IFPRI), AGRODEP Working Paper 0034 (2016).

Borin, Alessandro and Michele Mancini. "Follow the value-added: bilateral gross export accounting." Bank of Italy Working Papers 1026 (2015).

Bouët, Antoine, Yvan Decreux, Lionel Fontagné, Sébastien Jean, and David Laborde. “Assessing applied protection across the world." Review of International Economics 16(5) (2008a): 850-863 .

Bouët, Antoine, Santosh Mishra, and Devesh Roy. "Does Africa trade less than it should and why? The role of market access and domestic factors." IFPRI Discussion Paper 770 (2008b).

Bouët, Antoine, Lionel Cosnard and David Laborde. "Measuring trade integration in Africa.” IFPRI Discussion Paper 1667 (2017).

Brahmbhatt, Milan. "Measuring global economic integration: A review of the literature and recent evidence.” Working paper, The World Bank, 1998.

Brenton, Paul and Gözde Isik. De-fragmenting Africa : Deepening Regional Trade Integration in Goods and Services. Washington DC : World Bank, 2012.

Cappariello, Rita and Alberto Felettigh. "How does foreign demand activate domestic value-added? A comparison among the largest euro-area economies." Bank of Italy, Economic Research and International Relations Area, Temi di discussione. Economic working papers 1001 (2015). 
Cosnard, Lionel and David Laborde. "Measurement of trade in value-added using the MIRAGRODEP model and the GTAP 9 database.” IFPRI, mimeo (forthcoming).

Daudin, Guillaume, Christine Rifflart and Danielle Schweisguth. "Who produces for whom in the world economy?" The Canadian Journal of Economics 44, no.4 (2011): 1403-1437.

De Benedictis, Luca, Silvia Nenci, Gianluca Santoni, Lucia Tajoli, and Claudio Vicarelli. "Network analysis of World Trade using the BACI-CEPII dataset." Global Economy Journal 14(3-4) (2014): 287-343.

De Lombaerde, Philippe and Lelio Iapadre. Macroeconomics and Beyond. Essays in honour of Wim Meeusen, "Globalization Indicators: Ways Forward”, Antwerp: Garant, 2012: 159-174.

Dijkstra, Edsger W. "A note on two problems in connexion with graphs." Numerische Mathematik 1 (1959): 269-271.

Foroutan, Faezeh and Lant Pritchett. "Intra Sub-Saharan African trade: is it too little?" Journal of African Economies 2, no.1 (1993): 74-105.

Gaulier, Guillaume and Soledad Zignago. "BACI: International Trade Database at the Product- Level. The 1994-2007 Version.” CEPII Working Paper 23 (2010).

Guimbard, Houssein, Sébastien Jean, Mondher Mimouni and Xavier Pichot. "MAcMap-HS6 2007, An exhaustive and consistent measure of applied protection in 2007." CEPII Working Paper 2012-10 (2012).

Hamanaka, Shintaro. "The Selection of Trade Integration Indicators: Intraregional Share, Intensity, Homogeneous Intensity, and Introversion Index." ADB Economic Working Paper Series 455 (2015).

Harrison, Ann. "Openness and growth: A time-series, cross-country analysis for developing countries." Journal of Development Economics 48, no.2 (1996): 419-447.

Hummels, David. “Toward a Geography of Trade Costs”, Purdue University (2001). Hummels, David, and Georg Schaur. "Time as a Trade Barrier." NBER Working 
Papers 17758 (2012).

Hummels, David, Jun Ishii and Kei-Mu Yi. "The nature and growth of vertical specialisation in world trade." Journal of International Economics 54 (2001): 75-96.

Iapadre, Lelio, and Francesca Luchetti. "Trade Regionalisation and Openness in Africa". Paper presented at the workshop on "Transforming Political Structures: Security, Institutions, and Regional Integration Mechanisms", organized by the European Report on Development in Florence, Italy, April 16-17, 2009.

Johnson, Robert C. and Guillermo Noguera. "Accounting for intermediates: Production sharing and trade in value-added.” Journal of International Economics 86, no.2 (2012): 224-236.

Jones, Lin, Zhi Wang, Li Xin, and Christophe Degain. "The Similarities and Differences among Three Major Inter-Country Input-Output Databases and their Implications for Trade in Value-Added Estimates." U.S. International Trade Commission, Office of Economics Working Paper 12B (2014).

Kali, Raja and Javier Reyes. "The Architecture of Globalization: A Network Approach to International Economic Integration" (2006).

Kee, Hiau Looi, Alessandro Nicita, and Marcelo Olarreaga. "Import Demand Elasticities and Trade Distortions." Review of Economics and Statistics (2008): 666682.

Kee, Hiau Looi, Alessandro Nicita, and Marcelo Olarreaga. Estimating trade restrictiveness indices, Economic Journal 119 (2009): 172-199.

Koopman, Robert, William Powers, Zhi Wang and Shang-Jin Wei. "Give credit where credit is due: Tracing value-added in global production chains." NBER Working Paper Series 16426 (2010).

Koopman, Robert, Zhi Wang and Shang-Jin Wei. "Tracing Value-Added and Double Counting in Gross Exports." American Economic Review (2014): 459-494.

Laborde, David, Carmen Estrades, and Antoine Bouët. "A global assessment of the 
economic effects of export taxes", The World Economy (2013): 1333-1354.

Lesser, Caroline and Evdokia Moisé-Leeman. "Informal Cross-Border Trade and Trade Facilitation Reform in Sub-Saharian Africa”, OECD Trade Policy Papers 86 (2009).

Los, Bart, Marcel Timmer, and Gaaitzen J. de Vries. "Globalization or Regionalization? A New Approach to Measure International Fragmentation of Value Chains", Groningen Growth and Development Centre. GGDC Working Papers 138 (2013).

Mikic, Mia. "Commonly used trade integration and trade performance indicators in ESCAP." Presentation at $4^{\text {th }}$ ARTNeT Capacity Building Workshop for Trade Research, Phnom Penh, June 2-6, 2008.

OECD. Measuring globalisation: OECD Handbook on Economic Globalisation Indicators, Paris, OECD, 2005.

OECD. "TiVA 2015 indicators - definitions." Accessed June 13, 2016, https://www. oecd.org/sti/ind/tiva/TIVA_2015_Indicators_Definitions.pdf

Plummer, Michael G., David Cheong, and Shintaro Hamanaka. Methodology for impact assessment of free trade agreements. Asian Development Bank, 2010.

Riezman, Raymond G., John Whalley, and Shunming Zhang. "Metrics capturing the degree to which individual economies are globalized." Applied Economics (2013): 5046-5061.

Rose, Andrew K. 2000. “One Money, One Market: Estimating the Effect of Common Currencies on Trade." Economic Policy (2000): 8-45.

Sachs, Jeffrey D. and Andrew M. Warner. "Sources of Slow Growth in African Economies." Journal of African Economies 6, no.3 (1997): 335-376.

Samimi, Parisa, Guan Choo Lim and Abdul Aziz Buang 2011. "Globalization Measurement: Notes on Common Globalization Indexes", Journal of Knowledge Management 1, no.7 (2011): 1-20. 
Subramanian, Arvind and Natalia T. Tamirisa. "Africa's trade revisited.” IMF Working Paper 01/33, International Monetary Fund, 2011.

Tenreyro, Silvana. "On the trade impact of nominal exchange rate volatility." Journal of Development Economics 82, no.2 (2007): 485-508.

The World Bank. Doing Business 2016 Measuring Regulatory Quality and Efficiency. 2016.

Traoré, Fousseini and Cristina Mitaritonna. "African trade databases." WTO seminar on Tracking and Promoting Agricultural Trade Performance by African Countries, 2016.

UNECA and AfDB. Assessing Regional Integration in Africa IV: Enhancing IntraAfrican Trade vol. 4, United Nations Publications, 2010.

Vinokurov, Evgeny. The System of Indicators of Eurasian Integration 2009. Almaty, 2010: 160 .

Walkenhorst, Peter. "Indicators to monitor regional trade integration in Africa." Africa Trade Practice Working Paper Series 1, Africa Trade Practice (2013).

Walkenhorst, Peter. "Indicators to Monitor Deeper Regional Trade Integration in Africa." The World Bank, Report AUS7670 (2015).

World Trade Organization. Globalization of industrial production chains and measurement of trade in value-added. Paris: WTO, 2010.

Yang, Yongzheng and Sanjeev Gupta. "Regional Trade Arrangements in Africa: Past Performance and the Way Forward." African Development Review 19 (2007): 399431. 